\title{
Pluripotency and Immunomodulatory Signatures of Canine Induced Pluripotent Stem Cell-derived Mesenchymal Stromal Cells Are Similar to Harvested Mesenchymal Stromal Cells
}

\author{
Arash Shahsavari \\ University of Queensland \\ Prasanna Weeratunga \\ University of Queensland \\ Dmitry A. Ovchinnikov \\ University of Queensland \\ Deanne Whitworth ( $\sim$ d.whitworth@uq.edu.au ) \\ University of Queensland https://orcid.org/0000-0002-9097-0240
}

Research

Keywords: Canine induced pluripotent stem cells, Mesenchymal stem cells, Mesenchymal stromal cells, Pluripotency, Immunomodulation, Anti-inflammatory

Posted Date: July 2nd, 2020

DOI: https://doi.org/10.21203/rs.3.rs-39384/v1

License: (c) (1) This work is licensed under a Creative Commons Attribution 4.0 International License.

Read Full License

Version of Record: A version of this preprint was published at Scientific Reports on February 10th, 2021. See the published version at https://doi.org/10.1038/s41598-021-82856-3. 


\section{Abstract}

Background: With a view towards harnessing the therapeutic potential of canine mesenchymal stromal cells (cMSCs) as modulators of inflammation and the immune response, and to avoid the issues of the variable quality and quantity of harvested cMSCs, we examined the immunomodulatory properties of cMSCs derived from canine induced pluripotent stem cells (ciMSCs), and compared them to cMSCsharvested from adipose tissue (cAT-MSC) and bone marrow (cBM-MSC).

Methods and results: Deep sequencing of the ciMSC transcriptome confirmed that ciMSCsexpress more genes in common with cBM-MSCsthan with the ciPSCs from which they were derived. Both ciMSCs and CBM-MSCsexpress a range of pluripotency factors in common withthe ciPSCsincluding NANOG, POU5F1 (OCT-4), SOX-2, KLF-4, LIN-28A, MYC, LIF, LIFR, and TERT. However, ESRRB and PRDM-14, both factors associated with naïve, rather than primed, pluripotency were expressed only in the ciPSCs. LOXL-2, which is involved in epithelial to mesenchymal transition (EMT), is also expressed in ciMSCs and cBM-MSCs but notciPSCs. ciMSCsconstitutively express the immunomodulatory factors iNOS, GAL-9, TGF- $\beta 1$, PTGER-2aand VEGF, and the pro-inflammatory mediators COX-2,IL-1 $\beta$ and $I L-8$. When stimulated with the canine pro-inflammatory cytokines tumor necrosis factor-a (cTNF-a), interferon- $\gamma$ (cIFN- - ), or a combination of both, ciMSCsupregulated their expression of IDO,iNOS, GAL-9,HGF, TGF- $\beta 1$, PTGER-2a, $V E G F, C O X-2, I L-1 \beta$ and $/ L-8$. When co-cultured with mitogen-stimulated lymphocytes, ciMSCsdownregulated their expression of $i N O S, H G F, T G F-\beta 1$ and PTGER-2a, while increasing their expression of $C O X-2, I D O$ and $I L-1 \beta$.

Conclusions: Taken together, these findings suggest that ciMSCs possess similar immunomodulatory capabilities as harvested cMSCs and support further investigation into the potential use ofciMSCsfor the management of canine immune-mediated and inflammatory disorders.

\section{Background}

Mesenchymal stromal cells (MSCs), also called mesenchymal stem cells, are multipotent, self-renewing, non-hematopoietic stromal cells that are capable of differentiating into mesenchymal lineages including adipose tissue, bone, cartilage and muscle [1-3]. MSCs are commonly isolated from adipose tissue and bone marrow, but are also found in other tissues such as umbilical cord blood, placenta, skeletal muscle, synovial membranes, nervous tissue and dental pulp [4-6]. MSCs have acquired substantial clinical appeal owing to their immunomodulatory and anti-inflammatory properties [7-11]. The immunosuppressive functions of MSCs are triggered by the tissue microenvironment where proinflammatory cytokines such as interferon- $\gamma$ (IFN- $\gamma$ ), tumor necrosis factor-a (TNF-a), interleukin-1a (IL-1a) and interleukin-1 $\beta$ (IL-1 $\beta)$ are released from activated T cells [12-15]. In humans, MSCs derived from a variety of tissues, including adipose tissue, bone marrow and gingiva have been shown to inhibit the proliferation of CD $4+$ and CD8+, T cells, B cells and dendritic cells, and the maturation and activation of natural killer cells [16-19]. The MSC-derived soluble factors responsible for their immunomodulatory effects include indoleamine 2,3 dioxygenase (IDO), induced nitric oxide (iNOS), cyclooxygenase-2 (COX- 
2), vascular endothelial growth factor (VEGF), interleukin-10 (IL-10), hepatocyte growth factor (HGF), prostaglandin E2 (PGE2), transforming growth factor- $\beta 1$ (TGF- $\beta 1$ ) and haem oxygenase-1 (HO-1) [20-29]. More specifically, the immunosuppressive effect of MSCs is primarily mediated by IDO or iNOS, produced by human and mouse MSCs, respectively, following the stimulatory effect of pro-inflammatory cytokines on MSCs [25, 30-33]. Canine adipose tissue-derived MSCs (cAT-MSCs) have also been shown to modulate the immune response via the production of iNOS, TGF- $\beta 1$, HGF, IDO and PGE2, while bone marrow-derived MSCs (cBM-MSCs) secrete TGF- $\beta 1$ and VEGF $[25,34,35]$. In the horse, MSCs from bone marrow, adipose tissue, umbilical cord blood and Wharton's jelly that have been primed with TNF-a and/or IFN-y similarly inhibit the proliferation of T lymphocytes [36, 37], and analyses specifically on BMMSCs identified upregulated expression of IDO, iNOS, IL-6, COX-2 and VCAM-1 [37-40]. While MSCs can be harvested from a range of tissues, they constitute a very small proportion of the total cells collected: $0.001-0.01 \%$ in bone marrow aspirates and $0.05 \%$ of cells in adipose tissue [41, 42], posing a challenge in obtaining sufficient cells for therapeutic applications. To overcome this challenge, we have previously generated MSCs from canine induced pluripotent stem cells (ciMSCs) via inhibition of the TGF $\beta$ /activin signalling pathway [43]. These ciMSCs express MSC markers and show a comparable differentiation potential to harvested CAT-MSCs and CBM-MSCs, readily forming cartilage, bone and adipose tissue [43]. The current study has expanded the original characterisation of the ciMSCs by comparing their transcriptome with that of harvested cBM-MSCs and of the ciPSCs from which they were derived. Upon confirming that they cluster with the cBM-MSCs and not the ciPSCs, and with the intention of exploring their potential as an 'off-the-shelf' MSC-based therapy for controlling immune-mediated and inflammatory diseases in the dog, we further investigated their anti-inflammatory and immunomodulatory profiles in comparison with harvested cAT-MSC and cBM-MSCs.

\section{Materials And Methods}

The collection and use of animal tissues was approved by the Animal Ethics Committee at The University of Queensland under ethics approval numbers SVS/194/15, SVS/099/17 and SVS/ANRFA/453/18.

\section{Culture of ciMSCs, cAT-MSCs and cBM-MSCs}

Cultures of ciMSCs [43], commercially available adult cAT-MSCs (Regeneus Ltd, Australia), and harvested cBM-MSCs [43] were maintained in MSC-specific medium consisting of KnockOut Dulbecco's Modified Eagle's Medium (KnockOut DMEM; Gibco, Thermo Fisher Scientific, Australia) supplemented with 15\% (v/v) ESC-qualified fetal bovine serum (HyClone, GE Healthcare Life Sciences, Australia), $0.1 \mathrm{mM}$ NonEssential Amino Acid solution (NEAA; Gibco), and $2 \mathrm{mM}_{\mathrm{L}}$-glutamine (Gibco) at $37^{\circ} \mathrm{C}$ with $5 \% \mathrm{CO}_{2}$.

\section{RNA isolation, cDNA synthesis and quantitative polymerase chain reaction}

Total RNA was extracted using the NucleoSpin ${ }^{\circledR}$ RNA kit (Macherey-Nagel GmbH, Thermo Fisher Scientific) and complementary DNA was synthesized using the iScript Reverse Transcriptase kit (Bio-Rad 
Laboratories, Australia) according to the manufacturer's instructions. The comparative expression of immunomodulatory and anti-inflammatory factors was performed by real-time quantitative RT-PCR (qRTPCR) with the SsoFastEva Green Supermix (Bio-Rad) on a CFX-96 real time PCR detection system (Bio-

Rad). Data were normalised to the expression level of $c G A P D H$. Validated primers and their product sizes are listed in Supplementary Table 1. The cycling parameters for the qRT-PCR were: denaturation at $95^{\circ} \mathrm{C}$ for $3 \mathrm{~min}, 45$ amplification cycles $\left(95^{\circ} \mathrm{C}, 10 \mathrm{~s} ; 62^{\circ} \mathrm{C}, 20 \mathrm{~s}\right)$ and elongation at $75^{\circ} \mathrm{C}$ for $1 \mathrm{~min}$. Melt curve analysis was performed over a temperature range of $65-95^{\circ} \mathrm{C}$ in $0.5^{\circ} \mathrm{C}$ increments for $0.05 \mathrm{~s}$. The relative expression ratios of genes were calculated by the Delta $\mathrm{Ct}$ method. Dissociation curve analysis was implemented to confirm the specificity of the PCR products.

\section{Deep sequencing of ciMSC, cBM-MSC and ciPSC transcriptomes}

RNA was extracted from one line of each of the ciPSCs (Clone A), ciMSCs (derived from Clone A ciPSCs), and cBM-MSCs as described above. 100 base-pair paired-end mRNA sequencing was performed by the Australian Genome Research Facility Ltd (www.agrf.org.au) on an Illumina HiSeq 4000 platform. Primary sequence data underwent demultiplexing, quality control, alignment, transcript assembly, quantification and normalisation, followed by differential expression analysis, as performed by the AGRF. Sequence reads were screened for the presence of any cross-species contamination and mapped against the canine reference genome CanFam3.1 (GCA_000002285.2) (https://asia.ensembl.org/Canis_familiaris). Genes were defined as expressed if the $C P M \geq 1$. EdgeR was used to generate multidimensional scaling (MDS) plots using both raw gene counts and after normalisation by EdgeR's TMM algorithm to account for the different library sizes for each sample. Both the raw gene count and normalised gene count MDS plots were generated from the data of the 500 most variably expressed genes across all samples. Venn analysis was performed using the Venny tool at http://bioinfogp.cnb.csic.es/tools/venny. Due to financial and logistical constraints only one sample of the ciPSCs and ciMSCs, and cBM-MSCs from one individual, were used for RNA sequencing; therefore, the RNAseq data is indicative of genes that are expressed, but without the number of samples required to perform statistical analyses no comment can be made regarding differential expression between the cell types.

\section{In vitro stimulation of MSCs with pro-inflammatory cytokines}

CAT-MSCs, cBM-MSCs and ciMSCs were plated separately, in duplicate, at a density of $2 \times 10^{5} \mathrm{cells} / \mathrm{ml}$ with $1 \mathrm{ml}$ of MSC medium (as above) in flat-bottom 24-well cell culture plates (Costar, Corning Life Sciences, Australia). Each of the cAT-MSCs, cBM-MSCs and ciMSCs were cultured with either canine tumor necrosis factor- $a$ (cTNF-a) $(10 \mathrm{ng} / \mathrm{ml})$ (VWR International, Australia), canine interferon- $\gamma$ (cIFN- $\gamma$ ) (200 ng/ml) (VWR International), or both, at $37^{\circ} \mathrm{C}$ and $5 \% \mathrm{CO}_{2}$ for 48 hours.

\section{Isolation of leukocytes from canine blood}


$40 \mathrm{ml}$ of whole blood was aseptically collected in Vacuette blood collection tubes (InterPath Services, Australia) from two healthy adult mixed-breed dogs at the School of Veterinary Science, University of Queensland. Leukocytes were isolated using the ACCUSPIN System-Histopaque-1077 (Sigma-Aldrich, Australia) according to the manufacturer's instructions.

\section{Co-culture of CAT-MSCs and ciMSCs with mitogen- stimulated mixed canine leukocytes}

Leukocytes were maintained in medium consisting of RPMI-1640 medium (Sigma-Aldrich) supplemented with 10\% fetal calf serum (FCS; JRH Biosciences, Australia), 2 mM L-glutamine, 1\% NEAA, 1 mM sodium pyruvate (Gibco), 10000 units $/ \mathrm{ml}$ penicillin and $10000 \mu \mathrm{g} / \mathrm{ml}$ streptomycin (1\% Pen-Strep) (Gibco), and $50 \mu \mathrm{M}$ 2-mercaptoethanol (Gibco), in flat-bottom 24-well cell culture plates (Costar). The following cocultures were established, in independent duplicate samples, in a 24-well cell culture plate: a) $1 \times 10^{6}$ leukocytes and $1 \times 10^{5}$ cAT-MSCs; b) $1 \times 10^{6}$ leukocytes and $1 \times 10^{5}$ ciMSCs; c) $1 \times 10^{6}$ leukocytes; d) $1 \times$ $10^{5}$ cAT-MSCs and e) $1 \times 10^{5}$ ciMSCs. Concanavalin A (Sigma-Aldrich), a mitogenic stimulant, was added at a concentration of $25 \mu \mathrm{g} / \mathrm{ml}$ to stimulate the proliferation of the T lymphocytes. Cultures were maintained at $37^{\circ} \mathrm{C}$ in $5 \% \mathrm{CO}_{2}$ for 72 hours.

After 72 hours, lymphocytes were precipitated from the cell culture medium by centrifugation at $200 \mathrm{xg}$ for 2 min before freezing at $-80^{\circ} \mathrm{C}$. The culture medium from all wells was frozen at $-80^{\circ} \mathrm{C}$ for future analysis. CAT-MSCs and ciMSCs were enzymatically collected with TrypLE Express (Gibco) and the cell pellets stored at $-80^{\circ} \mathrm{C}$.

\section{Enzyme-linked immunoassays}

Culture supernatants were used to determine the concentration of TGF- $\beta 1$, VEGF, IL8 and IL-1 $\beta$ in the different co-culture groups. Canine-specific Quantikine ELISA kits for TGF- $\beta 1$ (R\&D Systems, USA), IL-8 (R\&D Systems), VEGF (R\&D Systems) and IL-1 $\beta$ (R\&D Systems) were used according to the manufacturer's instructions. Plates were analysed with an Infinite M200 (Tecan, Switzerland) microplate reader at the Australian National Fabrication Facility (ANFF, The University of Queensland, Brisbane, Australia).

\section{Statistical analysis}

Results are presented as the mean \pm standard error of the mean (SEM). The comparative analysis between treatment groups was conducted using one-way ANOVA and the means were compared with Student's t-test using the GraphPad7 Prism software (San Diego, CA, USA). Significance is defined as: ns $=$ not significant $p>0.05 ;{ }^{*} p \leq 0.05 ; * \star p \leq 0.005 ; * \star \star p \leq 0.0002 ; * \star \star \star p \leq 0.0001$.

\section{Results}

\section{Sequencing of ciMSC, cBM-MSC and ciPSC transcriptomes}


Venn analysis of expressed genes (CPM $\geq 1$ ) identified $83 \%$ of the 14,765 canine genes analysed as being co-expressed by all three cell types, including the cell surface markers CD73 (NT5E), CD90 (THY-1) and CD105 (ENDOG), confirming our original data [43], in addition to CD-44 (Fig. 1a, Table 1 and Supplementary data 1a). Only 135 genes, representing $0.9 \%$, were shared exclusively by the ciMSCs and the ciPSCs (Fig. 1a and Supplementary data 1a). In contrast, 818 genes (5.5\%) were expressed exclusively by the ciMSCs and cBM-MSCs including the cell surface proteins ANPEP(CD-13) and PDGFRA (CD-140a), cytokines FGF-2, FGF-5, IL13RA1, LEPR, NOV, PTN, SLIT-1 and TNC, and tumour necrosis factors TNFSF-13 and TNFSF-18 (Fig. 1a, Table 1 and Supplementary data 1a). cBM-MSCs also expressed the cytokines EDN-2, EDN-3, SEMA-3A and GREM-2, while ciMSCs expressed FGF-10 (Supplementary data 1a). Both ciMSCs and cBM-MSCs express the Toll-like receptors TLR-2 and TLR-9 (Table 1 and Supplementary data 1a). Expression of the chemokine receptor $C X C R-4$, which is essential for the homing of MSCs to sites of inflammation $[45,46]$, is also detectable in ciMSCs and cBM-MSCs, but not ciPSCs (Table 1 and Supplementary data 1a). 
Table 1

Key genes expressed by each of ciMSCs, cBM-MSCs and ciPSCs

\begin{tabular}{|lll|}
\hline Genes Expressed by & Genes Expressed by & Genes Expressed by \\
ciMSCs, cBM-MSCs \& ciPSCs & ciMSCs \& cBM-MSCs & ciPSCs \\
\hline CD73 (NT5E) & ACVR1C & CCND-1 \\
CD90 (THY-1) & ANPEP(CD-13) & ESRRB \\
CD105 (ENDOG) & CXCR-4 & FGF-4 \\
CD-44 & FGF-2 & PRDM-14 \\
DNMT-3A & FGF-5 & TLE-2 \\
DNMT-3B & IL13RA1 & \\
JARID-2 & LEPR & \\
KLF-4 & NOV & \\
LEF-1 & PDGFRA (CD-140a) \\
LIF & PTN & \\
LIFR & SATB-1 & \\
LIN-28A & SLIT-1 & \\
C-MYC & TLR-2 & \\
MYC-L & TLR-9 & \\
NANOG & TNC & \\
NR6A1 & TNFSF-13 & \\
POU2F1 & TNFSF-18 & \\
POU5F1 (OCT-4) & & \\
SF1 & & \\
SOX-2 & & \\
STAT-3 & & \\
TERT & & \\
TFAP2C & & \\
WNT-3 & & \\
\hline
\end{tabular}


Venn analysis using the transcriptome data for 224 pluripotency factors demonstrated that ciMSCs, cBMMSCs and ciPSCs co-express 213 (94.2\%) of these factors including DNMT-3A, DNMT-3B, JARID-2, KLF-4, LEF-1, LIF, LIFR, LIN-28A, C-MYC, MYC-L, NANOG, NR6A1, POU2F1, POU5F1 (OCT-4), SF1, SOX-2, STAT-3, TERT, TFAP2C, WNT-3 and WNT-5A (Fig. 1b, Table 1 and Supplementary data 1b). ESRRB and PRDM-14, both of which are associated with naïve, rather than primed, pluripotency were expressed only in the ciPSCs (Table 1 and Supplementary data 1b). Also unique to the ciPSCs was the expression of CCND-1, FGF-4 and TLE-2 (Table 1 and Supplementary data 1b). Three factors associated with pluripotency were expressed only by the ciMSCs and cBM-MSCs: ACVR1C, FGF-5 and SATB-1 (Table 1 and Supplementary data 1b). Multidimensional scaling (MDS) plots, using both raw gene count (Fig. 1c) and normalised gene count (Fig. 1d) data, placed the ciMSCs and cBM-MSCs as a superimposed cluster while the ciPSCs formed a separate cluster.

\section{ciMSCs constitutively express immunomodulatory and anti- inflammatory factors and respond to priming with pro- inflammatory cytokines}

ciMSCs constitutively expressed the immunomodulatory factors inducible nitric oxide synthase (iNOS), galectin-9 (GAL-9), transforming growth factor- $\beta 1$ (TGF- $\beta 1$ ), prostaglandin receptor-2a (PTGER-2a) and vascular endothelial growth factor (VEGF), and the pro-inflammatory factors cyclooxygenase-2 (COX2), interleukin-1 $\beta$ (IL-1 $\beta$ ) and interleukin-8 (IL-8) (Fig. 2). cAT-MSCs had a similar constitutive expression profile, although they expressed iNOS and HGF at significantly lower levels (Supplementary table 2), and VEGF at significantly higher levels (Supplementary table 2), than ciMSCs (Fig. 2).

Expression of $i N O S$ by ciMSCs was significantly higher than for CAT-MSCs and cBM-MSCs in all three treatment groups with cTNF-a, cIFN- $\gamma$ or a combination of both (cTNF-a/cIFN- $\gamma$ ) (Fig. 3a; Supplementary table 2). While expression of iNOS by ciMSCs and cAT-MSCs decreased significantly from constitutive levels when treated with cTNF-a and cIFN-y (Fig. 3a; Supplementary table 2), when cultured with both in combination (cTNF- $a / c I F N-\gamma$ ) the expression of $i N O S$ increased almost 10 -fold in ciMSCs but remained unchanged in cAT-MSCs (Fig. 3a; Supplementary table 2).

ciMSCs expressed higher levels of GAL-9 than CAT-MSCs and cBM-MSCs in response to CTNF-a and cIFNY (Fig. 3b; Supplementary table 2), and upregulated their expression by around 10-20 fold as compared to constitutive levels across all three treatment groups (Fig. 3b; Supplementary table 2). Expression of COX-2 was similarly higher in ciMSCs as compared to cAT-MSCs and cBM-MSCs when treated with cTNFa and cIFN-y (Fig. 3c; Supplementary table 2). While cBM-MSCs expressed COX-2 at barely detectable levels across all three treatment groups, both cAT-MSCs and ciMSCs upregulated their expression by approximately 100 fold in response to cTNF-a/cIFN-y (Fig. 3c; Supplementary table 2).

CAT-MSCs and ciMSCs expressed similar levels of TGF- $\beta 1$ constitutively (Fig. 2), but cAT-MSCs showed a stronger transcriptional response to cTNF- $a$ and cIFN- $\gamma$ than did ciMSCs, while they expressed similar levels of upregulated transcription when exposed to combined cTNF-a/cIFN-ץ (Fig. 3d; Supplementary 
table 2). Expression of PTGER-2a was highest in ciMSCs as compared to cAT-MSCs and cBM-MSCs, and was most significantly upregulated when they were cultured with cIFN- $\gamma$ and cTNF-a/cIFN- $\gamma$ (Fig. 3e; Supplementary table 2). Only cBM-MSCs showed detectable expression of indoleamine 2, 3 dioxygenase (IDO) in cultures with cTNF-a, while cAT-MSCs expressed the highest levels when cells were exposed to CIFN- $\gamma$; however, all three types of MSCs responded to stimulation with cTNF-a/cIFN- (Fig. 3f; Supplementary table 2).

Expression of $H G F$ was restricted predominantly to cAT-MSCs across all three treatment groups (Fig. 3g; Supplementary table 2). Similarly, VEGF was also most strongly expressed by CAT-MSCs, with significantly lower levels of expression detected in cBM-MSCs and ciMSCs (Fig. 3h; Supplementary table 2). While cAT-MSCs and ciMSCs expressed similar levels of $I L-8$ constitutively, the ciMSCs showed the most increased response to all three treatments, with the strongest response to cTNF-a (Fig. 3i; Supplementary table 2). Expression of IL-1 $\beta$ remained relatively unchanged in ciMSCs cultured with cTNF- $a$, clFN- $\gamma$ and cTNF-a/cIFN- $\gamma$; similarly, cBM-MSCs maintained consistent levels of expression across all three treatment groups (Fig. 3j; Supplementary table 2). In contrast, cAT-MSCs significantly downregulated their expression compared to constitutive levels (Fig. 3j; Supplementary table 2).

\section{Effect of mitogen-stimulated canine lymphocytes on inflammatory cytokine expression of MSCs}

When co-cultured with mitogen-stimulated lymphocytes, ciMSCs significantly downregulated their expression of iNOS, TGF- $\beta 1$, HGF and PTGER-2a (Fig. 4; Supplementary table 3). Although HGF expression levels also significantly decreased, transcription levels in the control cultures were so low that they are likely not indicative of expression (Fig. 4; Supplementary table 3). cAT-MSCs downregulated their expression of TGF- $\beta 1$ and VEGF, while iNOS and PTGER-2a remained unchanged (Fig. 4; Supplementary table 3). In response to co-culture, ciMSCs upregulated their expression of $C O X-2$ and $I D O$, and both ciMSCs and CAT-MSCs increased their expression of $I L-1 \beta$ (Fig. 4; Supplementary table 3). Expression of GAL- 9 and $I L-8$ increased in CAT-MSCs but remained unchanged in ciMSCs, while expression of VEGF decreased in CAT-MSCs and was unchanged in ciMSCs (Fig. 4; Supplementary table 3).

\section{Effect of MSCs on inflammatory cytokine expression of mitogen-stimulated canine lymphocytes}

Lymphocytes cultured with ciMSCs and cAT-MSCs downregulated their expression of GAL-9, PTGER-2a and $V E G F$, while the expression of $i N O S, I D O, I L-8$ and $I L-1 \beta$ were unchanged (Fig. 5; Supplementary table 4). In contrast, lymphocytes co-cultured with cAT-MSCs increased their expression of COX-2, TGF- $\beta 1$ and possibly $H G F$, although expression levels are so low as to be near the detection threshold (Fig. 5;

Supplementary table 4).

\section{Effects of co-culture on the secretion of factors by lymphocytes and MSCs}


The concentrations of canine IL-1 $\beta$, IL-8, TGF- $\beta 1$ and VEGF were measured in the supernatant collected from cultures of lymphocytes, ciMSCs and CAT-MSCs, and co-cultures of lymphocytes with each of ciMSCs and cAT-MSCs. In agreement with the qRT-PCR data, both ciMSCs and CAT-MSCs produce IL-1 $\beta$, IL-8, TGF- $\beta 1$ and VEGF (Fig. 6; Supplementary table 5). Furthermore, the relative expression levels of the genes between the two types of MSCs is reflected at the protein level with VEGFRNA and protein expression significantly higher in CAT-MSCs as compared to ciMSCs, while all other factors are expressed at similar levels for both RNA and protein (Fig. 6; Supplementary table 5). Lymphocytes similarly produce all four factors (Fig. 6; Supplementary table 5).

Based on the qRT-PCR data that showed lymphocytes did not alter their transcription of $I L-1 \beta$ in response to co-culture with either ciMSCs or CAT-MSCs, but both types of MSCs increased their transcription of IL$1 \beta$ when co-cultured, the increase in IL-1 $\beta$ measured in the medium from co-cultures is likely produced by the ciMSCs and CAT-MSCs rather than the lymphocytes (Fig. 6; Supplementary table 5). In contrast, based on the qRT-PCR data, the increase in IL-8 in co-cultures is more likely from the cAT-MSCs and lymphocytes than from the ciMSCs (Fig. 6; Supplementary table 5).

Both ciMSCs and CAT-MSCs downregulated their expression of TGF- $\beta 1$ when co-cultured, while lymphocyte expression, which was lower than that observed in the MSCs, increased or remained unchanged, when co-cultured with cAT-MSCs and ciMSCs, respectively. Thus, lower levels of TGF- $\beta 1$ were measured in the medium of co-cultured ciMSCs and CAT-MSCs than when the cells were cultured alone, and are similar to the levels detected in medium from lymphocyte cultures (Fig. 6; Supplementary table $5)$.

Both cAT-MSCs and lymphocytes expressed significantly higher levels of VEGF than ciMSCs and downregulated their expression in co-culture. This dynamic is reflected at the protein level where cATMSC/lymphocyte co-cultures have VEGF levels in between the levels for each when cultured separately, and the measurement for ciMSC/lymphocyte co-cultures are higher than the ciMSCs cultured alone but lower than the levels measured for lymphocytes or cAT-MSC/lymphocyte co-cultures (Fig. 6; Supplementary table 5).

\section{Discussion}

In this study we compared the transcriptome of ciMSCs with cBM-MSCs and ciPSCs and show expression of key pluripotency factors by three cell types. Previous studies have similarly demonstrated the expression of pluripotency factors by canine MSCs isolated from adipose tissue [47], bone marrow $[43,47]$ and amniotic fluid [48]. In contrast, ESRRB and PRDM-14, both factors associated with naïve, rather than primed, pluripotency [49-52] are expressed only in the ciPSCs and not the ciMSCs or CBMMSCs, which is not surprising since the ciPSCs are pluripotent $[43,53]$ while both types of MSCs are multipotent [43]. Also unique to the ciPSCs is the expression of FGF-4 which, in the mouse embryo, is secreted by the epiblast cells of the inner cell mass (ICM) under transcriptional regulation by Oct- 4 and 
Sox-2 [54] where it is thought to play a role in the development of the embryo through the conversion of the ICM into primitive endoderm $[55,56]$.

Endogenous and exogenously administered MSCs migrate towards tumours and sites of ischaemia and inflammation in response to a range of signalling molecules including the chemokine stromal cell-derived factor-1 (SDF-1), through interaction with its cognate receptor CXC chemokine receptor 4 (CXCR-4), which is expressed on the surface of MSCs [57-60]. Importantly, when considering future therapeutic applications, our ciMSCs express CXCR-4, as do the cBM-MSCs, while it is not expressed by the ciPSCs.

Studies in human MSCs from bone marrow, adipose tissue and umbilical cord blood have demonstrated an important role of signalling through Toll-like receptors (TLRs) in regulating the immunomodulatory effects, migration, proliferation and differentiation of MSCs [61-69]. Typically, human MSCs express high levels of TLR-3 and TLR-4, low levels of TLR-1, TLR-2, TLR-5, TLR-6 and TLR-9, and lack expression of TLR-7, TLR-8 and TLR-10. The expression profile of TLRs in our ciMSCs is very similar to that of the cBMMSCs and reflects the expression profile described in human MSCs with expression of $T L R-1, T L R-2, T L R$ 3, TLR-5, TLR-6 and TLR-9, and no expression of TLR-7, TLR-8 and TLR-10. However, unlike human MSCs, neither the ciMSCs nor the cBM-MSCs expressed TLR-4. This lack of $T L R-4$ expression is very surprising since TLR-4 signalling is responsible for priming human MSCs towards a pro-inflammatory phenotype, while TLR-3 priming induces an anti-inflammatory response $[61,66]$. Based on limited studies of various canine cell types (not including MSCs) the expression of $T L R-4$ in the dog appears to follow a similar profile to that described for other species [70] and so we could reasonably expect canine MSCs to similarly express high levels of $T L R-4$. A search of the literature did not yield any insight as to a possible explanation for the lack of $T L R-4$ expression in our canine MSCs, except to note that the expression of $T L R-4$ by human Wharton's jelly-derived MSCs appears to be variable $[61,71]$ and so the lack of $T L R-4$ expression in our canine MSCs may reflect a species difference or perhaps an effect of culture conditions.

The transcriptome of our ciMSCs is more similar to that of the cBM-MSCs than that of the ciPSCs. This is in contrast to the data of Chow et al. [72] whose ciPSC-derived MSCs showed a gene expression profile that was markedly different from that of cAT-MSCs and cBM-MSCs, and much more closely resembled that of the ciPSCs from which they were generated. It is possible that the ciPSCs generated by Chow and colleagues [72] were in a more primed, rather than naïve, state of pluripotency and that this has affected the nature of the resultant ciPSC-derived MSCs. It is perhaps significant that the ciPSCs that we used to generate our ciMSCs show many of the hallmarks of naïve pluripotency including expression of ESRRB and PRDM-14.

MSC secretion of either IDO or iNOS, depending on the species, has been shown to suppress T cell proliferation [32, 73-76]. In human, IDO is the key mediator of T cell suppression [32, 77-81] while in mouse [80] and horse [82] iNOS is the major inhibitor of T cell activation. However, recent reports suggest that IDO, in addition to $i N O S$, may be involved in the immunomodulatory roles of equine MSCs [36, 38, 39]. In this study, both ciMSCs and CAT-MSCs constitutively express iNOS and when co-stimulated with 
cTNF- $\alpha$ and cIFN- $y$, ciMSCs upregulated their expression of iNOS by 10 fold. That cAT-MSCs did not show an increase in iNOS expression beyond constitutive levels, and CBM-MSCs expressed very low levels in response to cTNF-a/cIFN- $y$, is in keeping with the observations by Chow et al. [72] that cAT-MSCs and cBM-MSCs do not employ the iNOS/NO-mediated pathway for immunosuppression. In contrast, the strong upregulation of iNOS expression in ciMSCs is similar to observations in the horse where priming of equine bone marrow-derived MSCs with IFN-y or TNF-a/IFN- $\gamma$ similarly induced an upregulation of iNOS [83]. Expression of iNOS significantly decreased in ciMSCs co-cultured with mitogen-stimulated lymphocytes. This would appear to be at odds with our observation of an upregulation of iNOS in ciMSCs exposed to CIFN- $\mathrm{y} / \mathrm{cTNF}-\mathrm{a}$. However, previous studies have demonstrated that the production of TNF- $\mathrm{a}$ by canine lymphocytes is reduced upon co-culture with cAT-MSCs [35], and the secretion of IFN-y by canine lymphocytes is similarly suppressed when co-cultured with cAT-MSCs and cBM-MSCs [84]. Thus, the decrease in iNOS expression by ciMSCs co-cultured with lymphocytes may be due to low levels of TNF-a and IFN- $\gamma$ being produced by the canine lymphocytes, possibly as a consequence of suppression by the ciMSCs.

All three types of MSCs responded to stimulation with cTNF-a/cIFN- $y$ by upregulating their expression of IDO. Kang et al. [35] similarly observed increased expression of IDO in canine AT.MSCs co-cultured with concanavalin-stimulated lymphocytes shown to be secreting cTNF-a and cIFN- $\gamma$. In our study, while ciMSCs significantly upregulated their expression of $I D O$ when co-cultured with concanavalin-stimulated lymphocytes, the transcript levels of IDO decreased in co-cultured cAT-MSCs. This discrepancy between our cAT-MSC data and that of Kang et al. [35] might reflect insufficient levels of IFN- $y$ and TNF-a being produced by the lymphocytes to stimulate the AT.MSCs, as discussed in the preceding paragraph.

Following TLR-3 priming, the release of TGF- $\beta 1$ by activated anti-inflammatory MSCs suppresses the proliferation and secretion of cytokines by $T$ lymphocytes and natural killer cells and also inhibits the stimulatory effect of dendritic cells on T lymphocytes [22, 25, 84-90]. Constitutive expression of TGF- $\beta 1$ by ciMSCs, cAT-MSCs and cBM-MSCs (RNAseq data) is in keeping with the data of other studies $[35,84$, 91] that have similarly demonstrated the constitutive transcription of TGF- $\beta 1$ in cBM-MSCs, cAT-MSCs and ciMSCs, respectively. While cAT-MSCs showed a stronger transcriptional response to CTNF- $a$ and CIFN- $\gamma$ than ciMSCs, both types of MSCs expressed similar levels of TGF- $\beta 1$ mRNA when cultured with combined cTNF-a/clFN- $\gamma$.

IL-8 is an MSC-derived chemokine released at the site of injury to enhance the migration and activation of neutrophils $[92,93]$. In this study, CAT-MSCs and ciMSCs expressed similar levels of IL-8 constitutively. The constitutive transcription of $I L-8$ has previously been described in canine AT.MSCs and human BM.MSCs [94]. ciMSCs showed the strongest response to all three treatments, particularly to cTNF-a. The induced upregulation of $I L-8$ by inflammatory stimuli has also been reported in human [95] and equine MSCs $[83,96]$.

\section{Conclusion}


In both their transcriptome and in their functional responses to inflammatory cytokines and mitogenstimulated lymphocytes, our ciMSCs are highly similar to harvested MSCs, supporting further investigation into their potential therapeutic applications for immune-mediated and inflammatory conditions in the dog.

\section{Abbreviations}

ACVR1C

Activin A Receptor Type 1C; ANPEP:Alanyl Aminopeptidase; cAT-MSCs:Canine Adipose Tissue-derived Mesenchymal Stromal Cells; cBM-MSCs:Canine Bone Marrow-derived Mesenchymal Stromal Cells; CCN3:Cellular Communication Network Factor 3; CCND-1:Cyclin D-1; CDH-1:Cadherin-1; clFN-ү:Canine Interferon-ү; ciMSCs:Canine Induced Pluripotent Stem Cell-derived Mesenchymal Stromal Cells; ciPSCs:Canine Induced Pluripotent Stem Cells; cMSCs:Canine Mesenchymal Stromal Cells; COX2:Cyclooxygenase-2; cTNF-a:Canine Tumor Necrosis Factor-a; CXC-4:Chemokine Receptor-4; DNMT3A:DNA Methyltransferase 3 Alpha; DNMT-3B:DNA Methyltransferase 3 Beta; EDN-2:Endothelin-2; EDN3:Endothelin-3; EMT:Epithelial-Mesenchymal Transition; ESRRB:Estrogen Related Receptor Beta; FGF2:Fibroblast Growth Factor-2; FGF-4:Fibroblast Growth Factor-4; FGF-5:Fibroblast Growth Factor-5; FGF10:Fibroblast Growth Factor-10; GADD:Growth Arrest and DNA Damage; GAL-9: Galectin-9; GREM2:Gremlin-2; HCK:Hemopoietic Cell Kinase; HGF:Hepatocyte Growth Factor; H01:Haem oxygenase-1; ICM:Inner Cell Mass; IDO:Indoleamine 2, 3-Dioxygenase; IFN- $\gamma:$ Interferon- $\gamma ;$ IL-1 $\beta$ :Interleukin-1 $\beta$; IL8:Interleukin-8; IL13RA:Interleukin 13 Receptor Subunit Alpha; iNOS:Inducible Nitric Oxide Synthase; IRS1:Insulin Receptor Substrate 1; JARID-2:Jumonji and AT-Rich Interaction Domain Containing 2; KLF4:Kruppel Like Factor-4; LEF-1:Lymphoid Enhancer Binding Factor 1; LEPR:Leptin Receptor; LIF:Leukemia Inhibitory Factor; LIFR:Leukemia Inhibitory Factor Receptor; LIN-28A:Lin-28 Homolog A; LOXL-2:Lysyl Oxidase Like 2; MEF-2C:Myocyte Enhancer Factor-2C; MITF:Melanocyte Inducing Transcription Factor; NEAA:Non-Essential Amino Acid; NR6A1:Nuclear Receptor Subfamily 6 Group A Member 1;

OCLN:Occludin; OCT-4:Octamer-binding Transcription Factor 4; PDGFC:Platelet Derived Growth Factor C; PDGFRA:Platelet Derived Growth Factor Receptor Alpha; PGE2:Prostaglandin E2; POU5F1:POU Domain, Class 5, Transcription Factor 1; PRDM-14:PR Domain Zinc Finger Protein 14; PTGER-2a:Prostaglandin receptor-2a; PTN:Pleiotrophin; SALL-3:Spalt Like Transcription Factor 3; SATB-1:SATB Homeobox-1; SDF1:Stromal Cell-Derived Factor 1; SEMA-3A:Semaphorin-3A; SF1:Steroidogenic factor 1; SLIT-1:Slit Guidance Ligand 1; SOX-2:SRY (sex determining region Y)-box 2; STAT-3:Signal Transducer and Activator of Transcription-3; TERT:Telomerase Reverse Transcriptase; TFAP2C:Transcription Factor AP-2 Gamma; TGF- $\beta 1$ :Transforming growth factor- $\beta 1$; TLE-2:Transducin Like Enhancer of Split-2; TLR-1:Toll-Like Receptor 1; TLR-2:Toll-like receptor 2; TLR-3:Toll-Like Receptor 3; TLR-4:Toll-Like Receptor 4; TLR-5:TollLike Receptor 5; TLR-6:Toll-Like Receptor 6; TLR-7:Toll-Like Receptor 7; TLR-8:Toll-Like Receptor 8; TLR9:Toll-Like Receptor 9; TLR-10:Toll-Like Receptor 10; TNC:Tenascin C; TNF:Tumour Necrosis Factor; TNFSF-13:TNF Superfamily Member-13; TNFSF-18:TNF Superfamily Member-18; VCAM-1:Vascular Cell Adhesion Molecule-1; VEGF:Vascular Endothelial Growth Factor; WNT-3:Wnt Family Member-3; WNT-

5A:Wnt Family Member-5A. 


\section{Declarations}

\section{Acknowledgements}

We are grateful to Ms Jane Sun, Australian Institute for Bioengineering and Nanotechnology, and Ms Samantha Kempster, School of Veterinary Science, The University of Queensland, for their technical assistance and helpful discussion. The authors are grateful for the support ofgrants from the Morris Animal Foundation (D18CA-077) and the Kibble Foundation (2015002711) to DW.

\section{Authors' contributions}

AS was responsible for experimental design, collection and assembly of data, data analysis andinterpretationandmanuscript writing. PW was responsible for the collection of data. DO was responsible for data analysis and interpretation, andmanuscript writing. DW was responsible for conception and experimental design,financial support, data analysis andinterpretation, andmanuscript writing. All authorsgave finalapproval of the manuscript.

\section{Funding}

This study was supported by grants from the Morris Animal Foundation (D18CA-077) and the Kibble Foundation (2015002711) to Deanne J. Whitworth and an Australian Government Research Training Program Scholarship awarded to Arash Shahsavari.

\section{Availability of data and materials}

The datasets used and analysed during the current study are available fromthe corresponding author on reasonable request.

\section{Ethics approval and consent to participate}

The collection and use of animal tissues was approved by the Animal Ethics Committee at The University of Queensland under ethics approval numbers SVS/194/15, SVS/099/17 and SVS/ANRFA/453/18.

\section{Consent for publication}

Not applicable

\section{Competing interests}

The authors declare that they have no competing interests.

\section{References}

1. Pittenger MF, Mackay AM, Beck SC, Jaiswal RK, Douglas R, Mosca JD, Moorman MA, Simonetti DW. $S$ Craig and DR Marshak. Multilineage potential of adult human mesenchymal stem cells. Science. 
1999;284:143-7.

2. Ferrari G, Angelis D, Coletta M, Paolucci E, Stornaiuolo A. G Cossu and F Mavilio. Muscle regeneration by bone marrow-derived myogenic progenitors. Science. 1998;279:1528-30.

3. Mackay AM, Beck SC, Murphy JM, Barry FP, Chichester CO, Pittenger MF. Chondrogenic differentiation of cultured human mesenchymal stem cells from marrow. Tissue Eng. 1998;4:41528.

4. Jackson WM, Nesti LJ, Tuan RS. Potential therapeutic applications of muscle-derived mesenchymal stem and progenitor cells. Expert Opin Biol Ther. 2010;10:505-17.

5. Zhang Q, Shi S, Liu Y, Uyanne J, Shi Y, Shi S, Le AD. Mesenchymal stem cells derived from human gingiva are capable of immunomodulatory functions and ameliorate inflammation-related tissue destruction in experimental colitis. J Immuno. 2009;183:7787-98.

6. Pierdomenico L, Bonsi L, Calvitti M, Rondelli D, Arpinati M, Chirumbolo G, Becchetti E, Marchionni C, Alviano F, Fossati V. Multipotent mesenchymal stem cells with immunosuppressive activity can be easily isolated from dental pulp. Transplantation. 2005;80:836-42.

7. Heldring N, Mager I, Wood MJA, Blanc KL, Andaloussi SEL. Therapeutic potential of multipotent mesenchymal stromal cells and their extracellular vesicles. Hum Gene Ther. 2015;26:506-17.

8. Hoogduijn MJ. Are mesenchymal stromal cells immune cells? Arthritis Res Ther. 2015;17:1-7.

9. De Schauwer C, Goossens K, Piepers S, Hoogewijs MK, Govaere JL, Smits K, Meyer E, Van Soom A. GR Van de Walle. Characterization and profiling of immunomodulatory genes of equine mesenchymal stromal cells from non-invasive sources. Stem Cell Res Ther. 2014; 5:1-13.

10. Dimarino AM, Caplan Al, Bonfield TL. Mesenchymal stem cells in tissue repair. Front Immunol. 2013;4:1-9.

11. Wood JA, Chung DJ, Park SA, Zwingenberger AL, Reilly CM, Ly I, Walker NJ, Vernau W, Hayashi K, Wisner ER, et al. Periocular and intra-articular injection of canine adipose-derived mesenchymal stem cells: an in vivo imaging and migration study. J Ocul Pharmacol Ther. 2012;28:307-17.

12. Shi M, Zhang Z, Xu RN, Lin H, Fu JL, Zou ZS, Zhang AM, Shia JF, Chen LM, Lv S, et al. Human mesenchymal stem cell transfusion is safe and improves liver function in acute-on-chronic liver failure patients. Stem Cells Transl Med. 2012;1:725-31.

13. Ren GW, Su JJ, Zhang LY, Zhao X, Ling WF, 'Huillie AL, Zhang JM, Lu YQ, Roberts Al, Ji WZ, et al. Species variation in the mechanisms of mesenchymal stem cell-mediated immunosuppression. Stem Cells. 2009;27:1954-62.

14. Eming SA, Krieg T, Davidson JM. Inflammation in wound repair: molecular and cellular mechanisms. J Invest Dermatol. 2007;127:514-25.

15. Luster AD, Alon R, von Andrian UH. Immune cell migration in inflammation: present and future therapeutic targets. Nat Immunol. 2005;6:1182-90.

16. Ben-Ami E, Berrih-Aknin S, Miller A. (2011). Mesenchymal stem cells as an immunomodulatory therapeutic strategy for autoimmune diseases. Autoimmun Rev. 2011; 10:410 - 15. 
17. Meirelles L, Fontes SAM, Covas DT, Caplan Al. Mechanisms involved in the therapeutic properties of mesenchymal stem cells. Cytokine Growth Factor Rev. 2009;20:419-27.

18. Benvenuto F, Ferrari S, Gerdoni E, Gualandi F, Frassoni F, Pistoia V, Mancardi G, Uccelli A. Human mesenchymal stem cells promote survival of T cells in a quiescent state. Stem Cells. 2007;25:175360.

19. Corcione A, Benvenuto F, Ferretti E, Giunti D, Cappiello V, Cazzanti F, Risso M, Gualandi F, Mancardi $\mathrm{GL}$, Pistoia V, et al. Human mesenchymal stem cells modulate B-cell functions. Blood. 2006;107:367-72.

20. Volarevic V, Gazdic M, Simovic Markovic B, Jovicic N, Djonov V, Arsenijevic N. Mesenchymal stem cell-derived factors: Immuno-modulatory effects and therapeutic potential. Biofactors. 2017;43:63344.

21. Kyurkchiev D, Bochev I, Ivanova-Todorova E, Mourdjeva M, Oreshkova T, Belemezova K, Kyurkchiev S. Secretion of immunoregulatory cytokines by mesenchymal stem cells. World J Stem Cells. 2014;6:552-70.

22. Liang $X$, Ding $Y$, Zhang $Y$, Tse HF, Lian Q. Paracrine mechanisms of mesenchymal stem cell-based therapy: current status and perspectives. Cell Transplant. 2014;23:1045-59.

23. Ma S, Xie N, Li W, Yuan B, Shi Y, Wang Y. Immunobiology of mesenchymal stem cells. Cell Death Differ. 2014;21:216-25.

24. Luz-Crawford P, Kurte M, Bravo-Alegria J, Contreras R, Nova-Lamperti E, Tejedor G, Noel D, Jorgensen C, Figueroa F, Djouad F, et al. Mesenchymal stem cells generate a CD4 + CD25 + Foxp3 + regulatory $T$ cell population during the differentiation process of Th1 and Th17 cells. Stem Cell Res Ther. 2013;4:1-12.

25. Lee WS, Suzuki Y, Graves SS, Iwata M, Venkataraman GM, Mielcarek M, Peterson LJ, Ikehara S, Torok-Storb B, Storb R. Canine bone marrow-derived mesenchymal stromal cells suppress alloreactive lymphocyte proliferation in vitro but fail to enhance engraftment in canine bone marrow transplantation. Biol Blood Marrow Transplant. 2011;17:465-75.

26. Singer NG, Caplan Al. Mesenchymal stem cells: mechanisms of inflammation. Annu Rev Pathol. 2011;6:457-78.

27. Gonzalez-Rey E, Gonzalez MA, Varela N, O'Valle F, Hernandez-Cortes P, Rico L, Buscher D, Delgado M. Human adipose-derived mesenchymal stem cells reduce inflammatory and $T$ cell responses and induce regulatory T cells in vitro in rheumatoid arthritis. Ann Rheum Dis. 2010;69:241-48.

28. Khatri M, TD, O'Brien, Sharma JM. Isolation and differentiation of chicken mesenchymal stem cells from bone marrow. Stem Cells Dev. 2009;18:1485-92.

29. Uccelli A, Moretta L, Pistoia V. Mesenchymal stem cells in health and disease. Nat Rev Immunol. 2008;8:726-36.

30. Ren G, Su J, Zhang L, Zhao X, Ling W, 'Huillie AL, Zhang J, Lu Y, Roberts Al, Ji W. Species variation in the mechanisms of mesenchymal stem cell-mediated immunosuppression. Stem Cells. 2009;27:1954-62. 
31. English K, Barry FP, Field-Corbett CP, Mahon BP. IFN-gamma and TNF-alpha differentially regulate immunomodulation by murine mesenchymal stem cells. Immunol Lett. 2007;110:91-100.

32. Meisel R, Zibert A, Laryea M, Göbel U, Däubener W, Dilloo D. Human bone marrow stromal cells inhibit allogeneic T-cell responses by indoleamine 2,3-dioxygenase-mediated tryptophan degradation. Blood. 2004;103:4619-21.

33. Staykova MA, Berven LA, Cowden WB, Willenborg DO, Crouch MF. Nitric oxide induces polarization of actin in encephalitogenic T cells and inhibits their in vitro trans-endothelial migration in a p70S6 kinase-independent manner. FASEB J. 2003;17:1337-39.

34. Wheat WH, Lyndah C, Kurihara JN, Regan RD, Coy JW, Webb TL, Dow SW. Suppression of canine dendritic cell activation/maturation and inflammatory cytokine release by mesenchymal stem cells occurs through multiple distinct biochemical pathways. Stem Cells Dev. 2017;26:249-62.

35. Kang JW, Kang KS, Koo HC, Park JR, Choi EW, Park YH. Soluble factors-mediated immunomodulatory effects of canine adipose tissue-derived mesenchymal stem cells. Stem Cells Dev. 2008;17:681-93.

36. Laura B, Rosa RA, Antonio R, José VF, Jorge A, Marta P, Jaime G, Rosa R, Pilar Z, Inmaculada M-B, et al. Priming equine bone marrow-derived mesenchymal stem cells with proinflammatory cytokines: Implications in immunomodulation-immunogenicity balance, cell viability, and differentiation potential. Stem Cells Dev. 2017;26:15-24.

37. Carrade DD, Wood JA, Granick JL, Walker NJ, Clark KC, Borjesson DL. Equine mesenchymal stem cels inhibit T cell proliferation through different mechanisms depending on tissue source. Stem Cell Dev. 2014;23:1258-65.

38. Cassano JM, Fortier LA, Hicks RB, Harman RM, Van de GR, Walle. Equine mesenchymal stromal cells from different tissue sources display comparable immune-related gene expression profiles in response to interferon gamma (IFN)-ү. Vet Immunol Immunopathol. 2018;202:25-30.

39. Barrachina L, Remacha AR, Romero A, Vazquez FJ, Albareda J, Prades M, Ranera B, Zaragoza P, Martin-Burriel I, Rodellar C. Effect of inflammatory environment on equine bone marrow derived mesenchymal stem cells immunogenicity and immunomodulatory properties. Vet Immunol Immunopathol. 2016;171:57-65.

40. Carrade DD, Lame MW, Kent MS, Clark KC, Walker NJ, Borjesson DL. Comparative analysis of the immunomodulatory properties of equine adult-derived mesenchymal stem cells. Cell Med. 2012;4:111.

41. Bieback K, Kern S, Kocaomer A, Ferlik K, Bugert P. Comparing mesenchymal stromal cells from different human tissues: bone marrow, adipose tissue and umbilical cord blood. Biomed Mater Eng. 2008;18:71-6.

42. Kern S, Eichler H, Stoeve J, Kluter H, Bieback K. Comparative analysis of mesenchymal stem cells from bone marrow, umbilical cord blood, or adipose tissue. Stem Cells. 2006;24:1294-301.

43. Whitworth DJ, Frith JE, Frith TJ, Ovchinnikov DA, Cooper-White JJ, Wolvetang EJ. Derivation of mesenchymal stromal cells from canine induced pluripotent stem cells by inhibition of the 
TGFß/activin signaling pathway. Stem Cells Dev. 2014;23:3021-33.

44. Khomtchouk BB, Hennessy JR, Wahlestedt C. Shinyheatmap: Ultra fast low memory heatmap web interface for big data genomics. PLoS One. 2017;12:e0176334.

45. Ryu CH, Park SA, Kim SM, Lim JY, Jeong CH, Jun JA, Oh JH, Park SH, Oh WI, Jeun S-S. Migration of human umbilical cord blood mesenchymal stem cells mediated by stromal cell-derived factor1/CXCR4 axis via Akt, ERK, and p38 signal transduction pathways. Biochem Biop Res Co. 2010;398:105-10.

46. Wynn RF, Hart CA, Corradi-Perini C, O'Neill L, Evans CA, Wraith JE, Fairbairn LJ, Bellantuono I. A small proportion of mesenchymal stem cells strongly expresses functionally active CXCR4 receptor capable of promoting migration to bone marrow. Blood. 2004;104:2643-45.

47. Takemitsu H, Zhao D, Yamamoto I, Harada Y, Michishita M, Arai T. Comparison of bone marrow and adipose tissue-derived canine mesenchymal stem cells. BMC Vet Res. 2012;8:150.

48. Choi SA, Choi HS, Kim KJ, Lee DS, Lee JH, Park JY, Kim EY, Li X, Oh HY, et al. Isolation of canine mesenchymal stem cells from amniotic fluid and differentiation into hepatocyte-like cells. In Vitro Cell Dev Biol Anim. 2013;49:42-51.

49. Yamaji M, Ueda J, Hayashi K, Ohta H, Yabuta Y, Kurimoto K, Nakato R, Yamada Y, Shirahige K, Saitou M. PRDM14 ensures naive pluripotency through dual regulation of signaling and epigenetic pathways in mouse embryonic stem cells. Cell Stem Cell. 2013;12:368-82.

50. Martello G, Sugimoto T, Diamanti E, Joshi A, Hannah R, Ohtsuka S, Göttgens B, Niwa H, Smith A. Esrrb is a pivotal target of the Gsk3/Tcf3 axis regulating embryonic stem cell self-renewal. Cell Stem Cell. 2012;11:491-504.

51. Percharde M, Lavial F, Ng J-H, Kumar V, Tomaz RA, Martin N, Yeo J-C, Gil J. S Prabhakar and HH Ng. Ncoa3 functions as an essential Esrrb coactivator to sustain embryonic stem cell self-renewal and reprogramming. Genes Dev. 2012;26:2286-98.

52. Grabole N, Tischler J, Hackett JA, Kim S, Tang F, Leitch HG. E Magnusdottir and MA Surani. Prdm14 promotes germline fate and naive pluripotency by repressing FGF signalling and DNA methylation. EMBO Rep. 2013;14:629-37.

53. Whitworth DJ, Ovchinnikov DA, Wolvetang EJ. Generation and characterization of LIF-dependent canine induced pluripotent stem cells from adult dermal fibroblasts. Stem Cells Dev. 2012;21:228897.

54. Yuan H, Corbi N, Basilico C, Dailey L. Developmental-specific activity of the FGF-4 enhancer requires the synergistic action of Sox-2 and Oct-3. Genes Dev. 1995;9:2635-45.

55. Krawchuk D, Honma-Yamanaka N, Anani S, Yamanaka Y. FGF4 is a limiting factor controlling the proportions of primitive endoderm and epiblast in the ICM of the mouse blastocyst. Dev Biol. 2013;384:65-71.

56. Yamanaka Y, Lanner F, Rossant J. FGF signal-dependent segregation of primitive endoderm and epiblast in the mouse blastocyst. Development. 2010;137:715-24. 
57. Karp JM, Teo GSL. Mesenchymal stem cell homing: the devil is in the details. Cell Stem Cell. 2009;4:206-16.

58. Zhang D, Fan G-C, Zhou X, Zhao T, Pasha Z, Xu M, Zhu Y, Ashraf M, Wang Y. Over-expression of CXCR4 on mesenchymal stem cells augments myoangiogenesis in the infarcted myocardium. $J$ Molecular Cellular Cardiol. 2008;44:281-92.

59. Marquez-Curtis LA, Janowska-Wieczorek A. Enhancing the migration ability of mesenchymal stromal cells by targeting the SDF-1/CXCR4 axis. Biomed Res Int. 2013; 2013: 1-13.

60. Wagner J, Kean T, Young R, Dennis JE, Caplan Al. Optimizing mesenchymal stem cell-based therapeutics. Curr Opin Biotechnol. 2009;20:531-36.

61. Sangiorgi B, Panepucci RA. Modulation of immunoregulatory properties of mesenchymal stromal cells by Toll-like receptors: Potential applications on GVHD. Stem Cells Int. 2016; 2016: 1-10.

62. Castro-Manrreza ME, Montesinos JJ. Immunoregulation by mesenchymal stem cells: biological aspects and clinical applications. J Immunol Res. 2015; 2015: 1-20.

63. DelaRosa O, Dalemans W, Lombardo E. Toll-like receptors as modulators of mesenchymal stem ccells. Front Immunol. 2012;3:1-8.

64. Mastri M, Shah Z, McLaughlin T, Greene CJ, Baum L, Suzuki G, Lee T. Activation of Toll-like receptor 3 amplifies mesenchymal stem cell trophic factors and enhances therapeutic potency. Am J Physiol Cell Physiol. 2012;303:C1021-33.

65. Raicevic G, Najar M, Pieters K, De Bruyn C, Meuleman N, Bron D, Toungouz M, Lagneaux L. Inflammation and Toll-like receptor ligation differentially affect the osteogenic potential of human mesenchymal stromal cells depending on their tissue origin. Tissue Eng Part A. 2012;18:1410-18.

66. Waterman RS, Tomchuck SL, Henkle SL, Betancourt AM. A new mesenchymal stem cell (MSC) paradigm: polarization into a pro-inflammatory MSC1 or an Immunosuppressive MSC2 phenotype. PloS One. 2010;5:e10088.

67. Liotta F, Angeli R, Cosmi L, Fili L, Manuelli C, Frosali F, Mazzinghi B, Maggi L, Pasini A, Lisi V. Toll-like receptors 3 and 4 are expressed by human bone marrow-derived mesenchymal stem cells and can inhibit their T-cell modulatory activity by impairing Notch signaling. Stem Cells. 2008;26:279-89.

68. Tomchuck SL, Zwezdaryk KJ, Coffelt SB, Waterman RS, Danka ES, Scandurro AB. Toll-like receptors on human mesenchymal stem cells drive their migration and immunomodulating responses. Stem Cells. 2008;26:99-107.

69. Pevsner-Fischer M, Morad V, Cohen-Sfady M, Rousso-Noori L, Zanin-Zhorov A, Cohen S, Cohen IR, Zipori D. Toll-like receptors and their ligands control mesenchymal stem cell functions. Blood. 2006;109:1422-32.

70. Vaure C, Liu Y. A comparative review of toll-like receptor 4 expression and functionality in different animal species. Front Immunol. 2014;5:1-15.

71. Raicevic G, Najar M, Stamatopoulos B, De Bruyn C, Meuleman N, Bron D, Toungouz M, Lagneaux L. The source of human mesenchymal stromal cells influences their TLR profile as well as their functional properties. Cell Immunol. 2011;270:207-16. 
72. Chow L, Johnson V, Regan D, Wheat W, Webb S, Koch P, Dow S. Safety and immune regulatory properties of canine induced pluripotent stem cell-derived mesenchymal stem cells. Stem Cell Res. 2017;25:221-32.

73. Sato K, Ozaki K, Oh I, Meguro A, Hatanaka K, Nagai T, Muroi K, Ozawa K. Nitric oxide plays a critical role in suppression of T-cell proliferation by mesenchymal stem cells. Blood. 2007;109:228-34.

74. Mellor A. Indoleamine. 3 dioxygenase and regulation of T cell immunity. Biochem Bioph Re Co. 2005;2:338:20-4.

75. Terness P, Bauer TM, Röse L, Dufter C, Watzlik A, Simon H, Opelz G. Inhibition of allogeneic T cell proliferation by indoleamine 2, 3-dioxygenase-expressing dendritic cells: mediation of suppression by tryptophan metabolites. J Exp Med. 2002;196:447-57.

76. Lu L, Bonham CA, Chambers FG, Watkins SC, Hoffman RA, Simmons RL, Thomson AW. Induction of nitric oxide synthase in mouse dendritic cells by IFN-gamma, endotoxin, and interaction with allogeneic T cells: nitric oxide production is associated with dendritic cell apoptosis. $\mathrm{J}$ Immunol. 1996;157:3577-86.

77. Wang G, Cao K, Liu K, Xue Y, Roberts Al, Li F, Han Y, Rabson AB, Wang Y, Shi Y. Kynurenic acid, an IDO metabolite, controls TSG-6-mediated immunosuppression of human mesenchymal stem cells. Cell Death Differ. 2018;25:1209-23.

78. Kadle RL, Soares MA, Rao N, Duckworth A, Park C, David J, Lopez CD, Zhou A, Brownstone N, Sartor RA, et al. Abstract 117: Microenvironmental cues enhance indoleamine 2,3-dioxygenase expression to facilitate mesenchymal stem cell-mediated immunosuppression. Plast Recons Surg. 2015;135:85.

79. Lewis CN, Chinnadurai R, Galipeau J. MSC immunomodulation and aryl hydrocarbons receptor activation by tryptophan catabolites. Cytotherapy. 2015;17:117.

80. Su J, Chen X, Huang Y, Li W, Li J, Cao K, Cao G, Zhang L, Li F, Roberts Al, et al. Phylogenetic distinction of iNOS and IDO function in mesenchymal stem cell-mediated immunosuppression in mammalian species. Cell Death Differ. 2014;21:388-96.

81. Miki T, Sun H, Lee Y, Tandin A, Kovscek A, Subbotin V, Fung J, Valdivia L. Blockade of tryptophan catabolism prevents spontaneous tolerogenicity of liver allografts. Transplantation Proc. 2001; 33 : $129-30$.

82. Remacha AR, Barrachina L, Álvarez-Arguedas S, Ranera B, Romero A. FJ Vázquez. Expression of genes involved in immune response and in vitro immunosuppressive effect of equine MSCs. Vet Immunol Immunopathol. 2015; 165: 107-18.

83. Cassano JM, Schnabel LV, Goodale MB, Fortier LA. Inflammatory licensed equine MSCs are chondroprotective and exhibit enhanced immunomodulation in an inflammatory environment. Stem Cell Res Ther. 2018;9:2-13.

84. Chow L, Johnson V, Coy J, Regan D, Dow S. Mechanisms of immune suppression utilized by canine adipose and bone marrow-derived mesenchymal stem cells. Stem Cells Dev. 2017;26:374-89.

85. Abdelmegeed SM, Mohammed S. Canine mammary tumors as a model for human disease. Oncol Lett. 2018;15:8195-205. 
86. Paterson YZ, Rash N, Garvican ER, Paillot R, Guest DJ. Equine mesenchymal stromal cells and embryo-derived stem cells are immune privileged in vitro. Stem Cell Res Ther. 2014;5:1-13.

87. Zhao S, Wehner R, Bornhäuser M, Wassmuth R, Bachmann M, Schmitz M. Immunomodulatory properties of mesenchymal stromal cells and their therapeutic consequences for immune-mediated disorders. Stem Cells Dev. 2010;19:607-14.

88. da Silva Meirelles L, Fontes AM, Covas DT, Caplan Al. Mechanisms involved in the therapeutic properties of mesenchymal stem cells. Cytokine Growth Factor Rev. 2009;20:419-27.

89. English K, Ryan J, Tobin L, Murphy M, Barry F, Mahon BP. Cell contact, prostaglandin E2 and transforming growth factor beta 1 play non-redundant roles in human mesenchymal stem cell induction of CD4 + CD25 Highforkhead box P3 + regulatory T cells. Clin Exp Immunol. 2009;156:149-60.

90. Di Nicola M, Carlo-Stella C, Magni M, Milanesi M, Longoni PD, Matteucci P, Grisanti S. AM Gianni. Human bone marrow stromal cells suppress T-lymphocyte proliferation induced by cellular or nonspecific mitogenic stimuli. Blood. 2002; 99:3838-43.

91. Screven R, Kenyon E, Myers MJ, Yancy HF, Skasko M, Boxer L, Bigley EC, Borjesson DL, Zhu M. Immunophenotype and gene expression profile of mesenchymal stem cells derived from canine adipose tissue and bone marrow. Vet Immunol Immunopathol. 2014;161:21-31.

92. Grau AJ, Reis A, Buggle F, Al-Khalaf A, Werle E, Valois N, Bertram M, Becher H. and C Grond-Ginsbach. Monocyte function and plasma levels of interleukin-8 in acute ischemic stroke. J Neurol Sci. 2001;192:41-7.

93. Kostulas N, Kivisäkk P, Huang Y, Matusevicius D, Kostulas V, Link H. Ischemic stroke is associated with a systemic increase of blood mononuclear cells expressing interleukin-8 mRNA. Stroke. 1998;29:462-66.

94. Kim DH, Yoo KH, Choi KS, Choi J, Choi SY, Yang SE, Yang YS, Im HJ, Kim KH, Jung HL, et al. Gene expression profile of cytokine and growth factor during differentiation of bone marrow-derived mesenchymal stem cell. Cytokine. 2005;31:119-26.

95. Romieu-Mourez R, Francois M, Boivin MN, Bouchentouf M, Spaner DE, Galipeau J. Cytokine modulation of TLR expression and activation in mesenchymal stromal cells leads to a proinflammatory phenotype. J Immunol. 2009;182:7963-73.

96. Vezina Audette R, Lavoie-Lamoureux A, Lavoie JP, Laverty S. Inflammatory stimuli differentially modulate the transcription of paracrine signaling molecules of equine bone marrow multipotent mesenchymal stromal cells. Osteoarthritis Cartilage. 2013;21:1116-24.

\section{Figures}


Figure 1

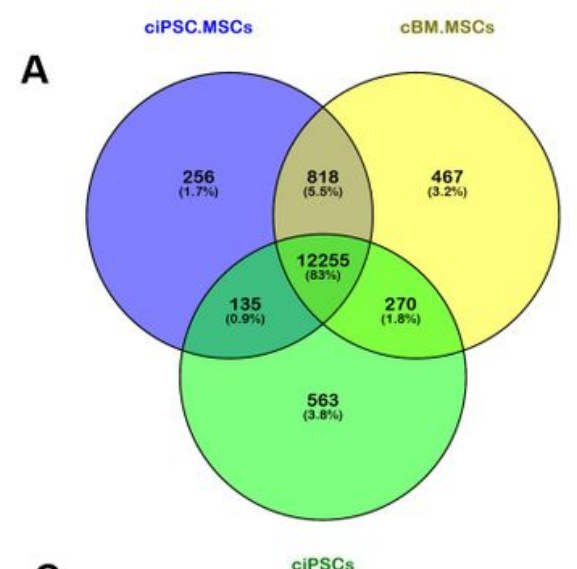

C

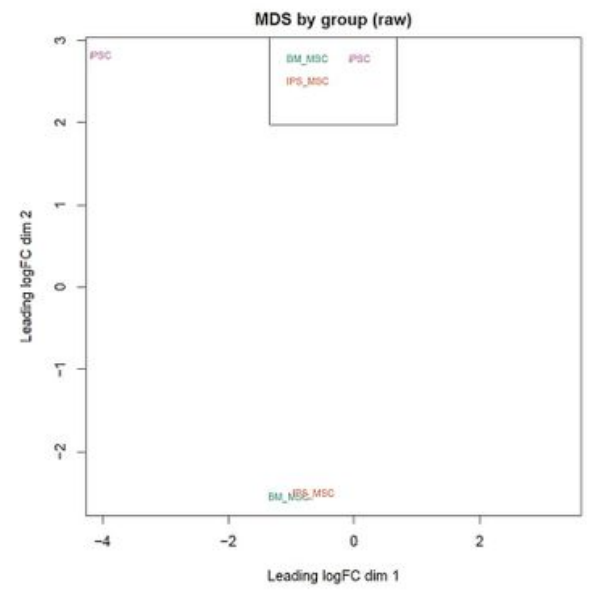

B

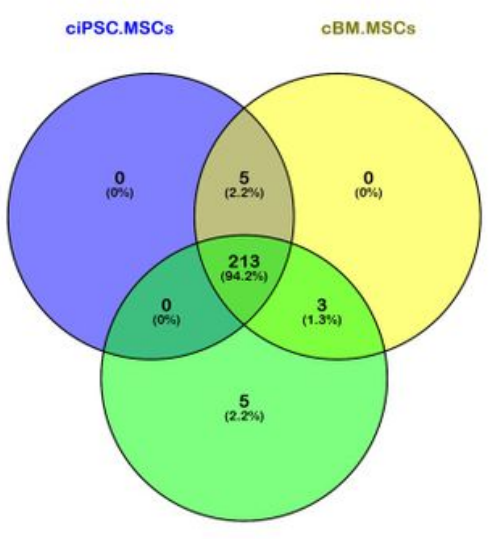

D

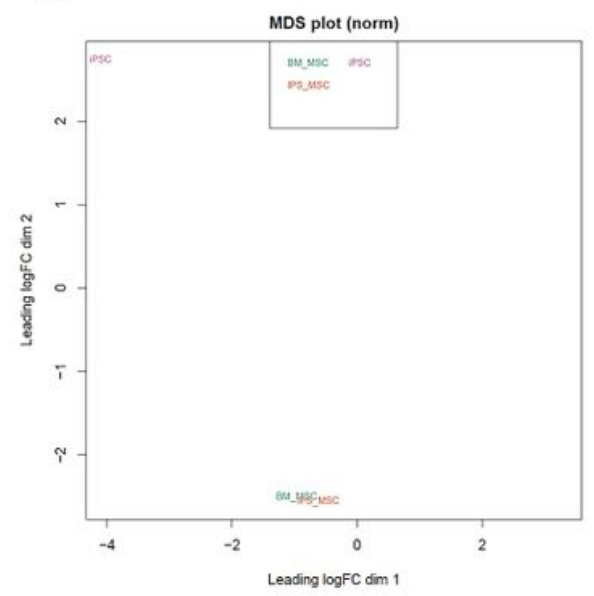

Shahsavari et al.

\section{Figure 1}

Canine iPSC-derived MSCs more closely resemble harvested bone marrow-derived MSCs than the iPSCs from which they were generated. (a)Venn analysis of expressed genes (CPM $\geq 1$ ) identified $83 \%$ of the 14,765 genes analysed as being co-expressed by canine bone marrow-derived mesenchymal stem cells (cBM-MSCs), canine induced pluripotent stem cell-derived mesenchymal stem cells (ciPSC-MSCs)and canine induced pluripotent stem cells (ciPSCs). 135 genes, representing $0.9 \%$, are shared by ciPSC-MSCs and the ciPSCs, while the ciPSC-MSCs and cBM-MSCs share 818 (5.5\%) genes in common. (b) Venn analysis using the transcriptome data for 224 pluripotency factors showed that ciPSC-MSCs, cBM-MSCs and ciPSCsco-express 213 (94.2\%) of these pluripotency factors. (c) Multidimensional scaling (MDS) plots using both raw gene count and (d) normalised gene count data placed the ciPSC-MSCs and cBMMSCs as a superimposed cluster while the ciPSCs formed a separate cluster. 

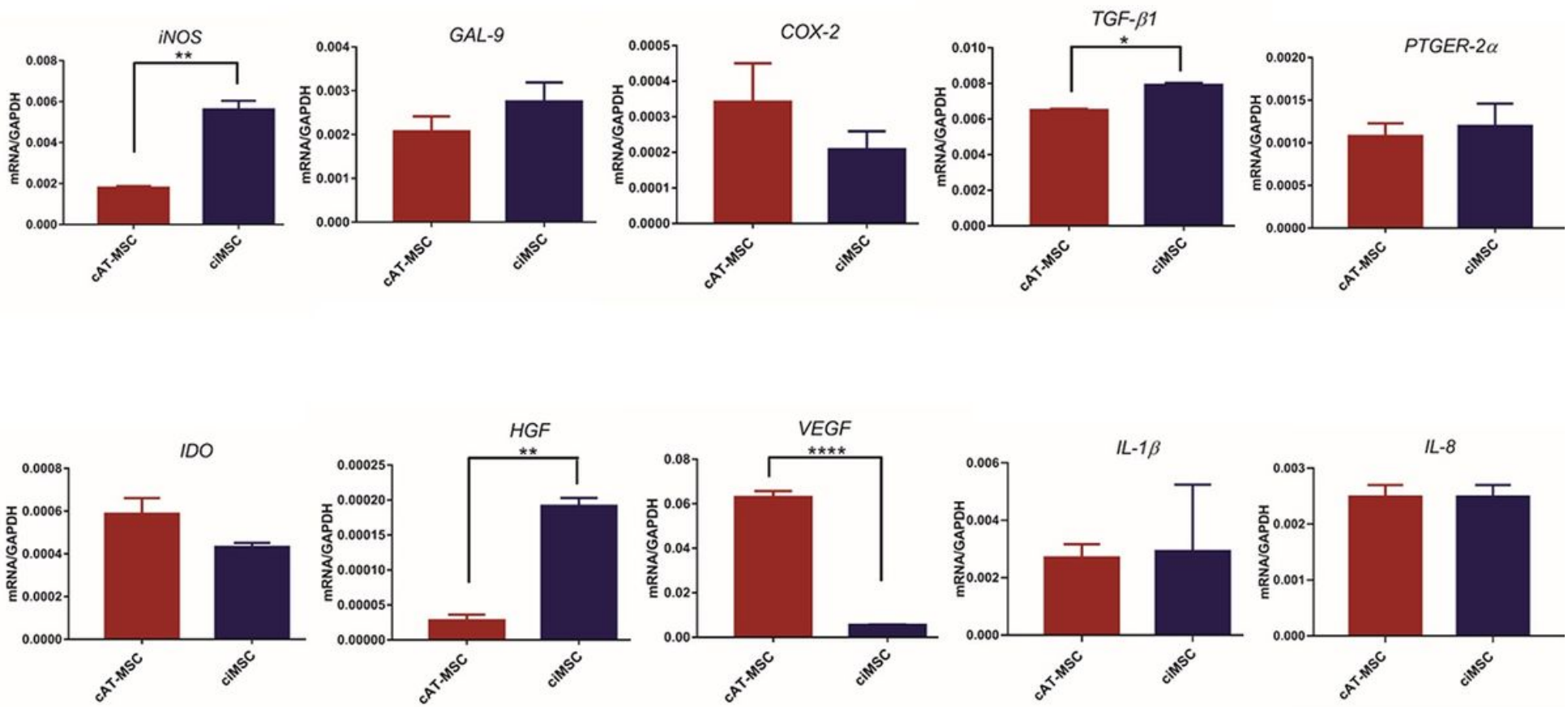

\section{Figure 2}

ciMSCs and CAT-MSCs constitutively express immunomodulatory and anti-inflammatory factors. ciMSCs and CAT-MSCshave similar constitutive expression profiles, although ciMSCs express higher levels of iNOSand HGF, and lower levels of VEGF, than the cAT-MSCs.Inducible nitric oxide (iNOS); Indoleamine 2,3 dioxygenase (IDO); Galectin-9 (GAL-9); Cyclooxygenase-2 (COX-2); Transforming growth factor- $\beta 1$ (TGF$\beta 1)$; Prostaglandin receptor-2a (PTGER-2a); Hepatocyte growth factor (HGF); Vascular endothelial growth factor (VEGF) ; Interleukin-8 (IL-8) and Interleukin-1 $\beta$ (IL-1 $\beta$ ). Significance is defined as: ns = not significant $p>0.05 ; * p \leq 0.05 ; * \star p \leq 0.005 ; * \star \star p \leq 0.0002 ; * \star \star \star ~ p \leq 0.0001$.

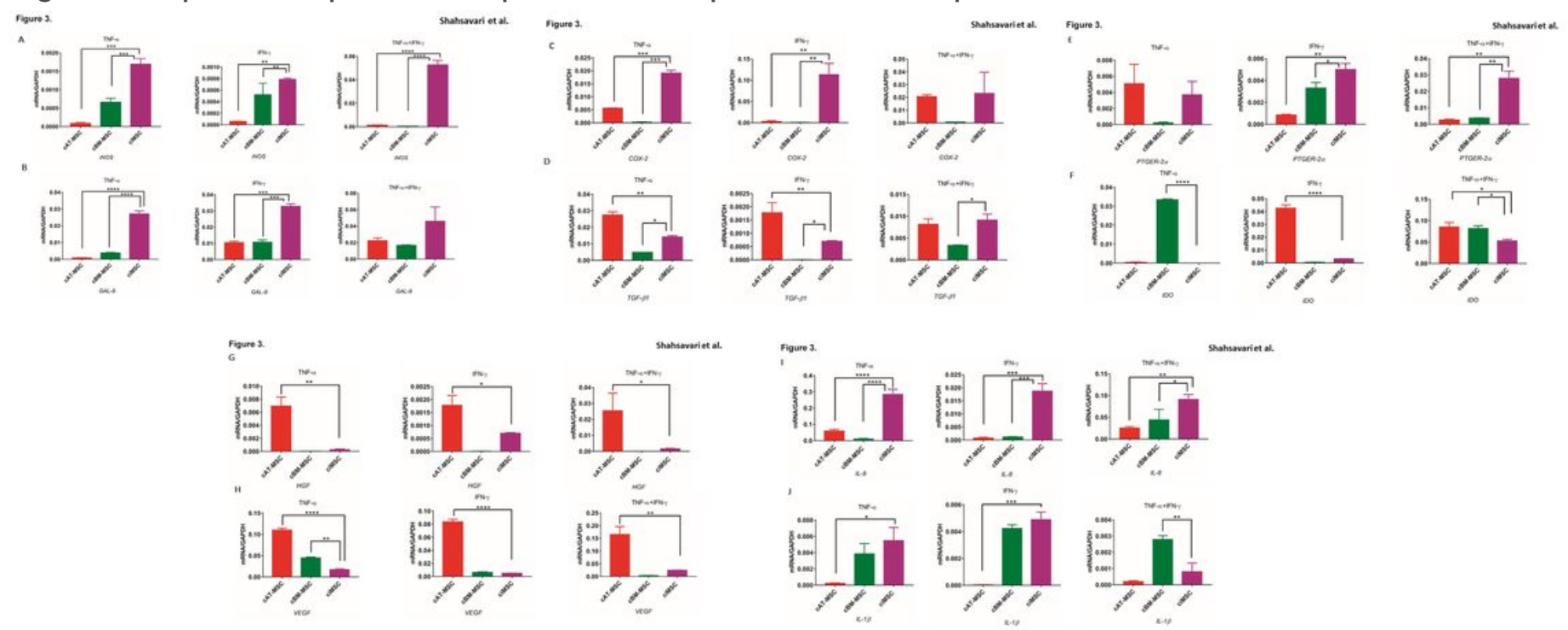




\section{Figure 3}

Response ofciMSCs,CAT-MSCs and cBM-MSCs to priming with pro-inflammatory cytokines canine tumor necrosis factor- $a$ (cTNF- $a$ ), canine interferon- $\gamma$ (cIFN- $\gamma$ ) and a combination of both (cTNF- $a+c I F N-\gamma)$. When stimulated with cTNF- $a$, cIFN- $\gamma$, or a combination of both, ciMSCs upregulated their expression of: (a) iNOS; (b) GAL-9;(c) COX-2; (d) TGF- $\beta$; (e) PTGER-2a; (f) IDO; (g) HGF; (h) VEGF; (i) IL-8 and(j) IL-

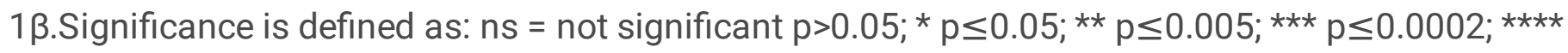
$\mathrm{p} \leq 0.0001$.

Figure 4.
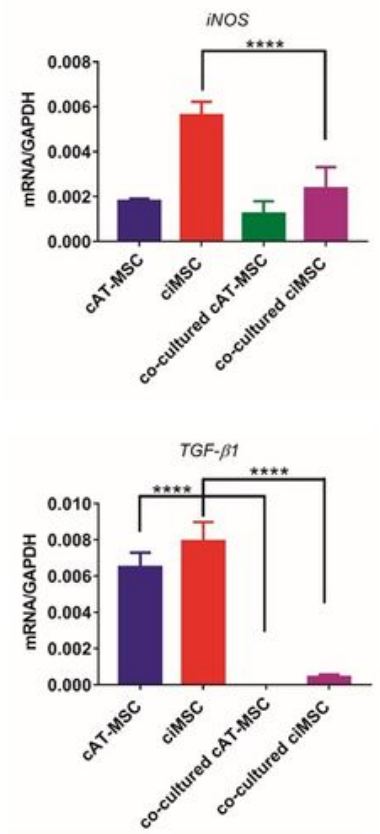
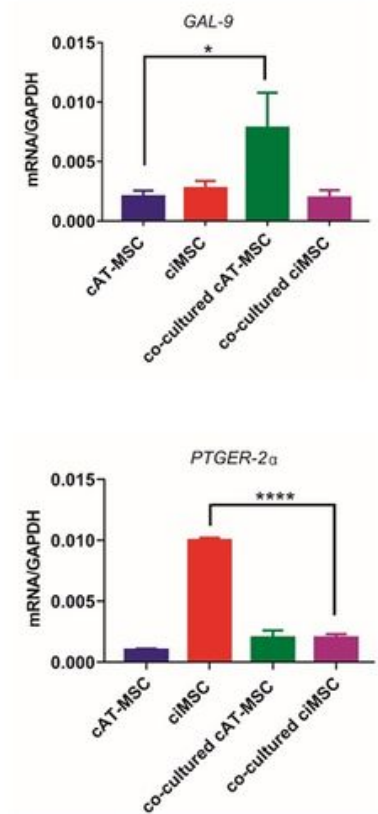

Shahsavariet al.
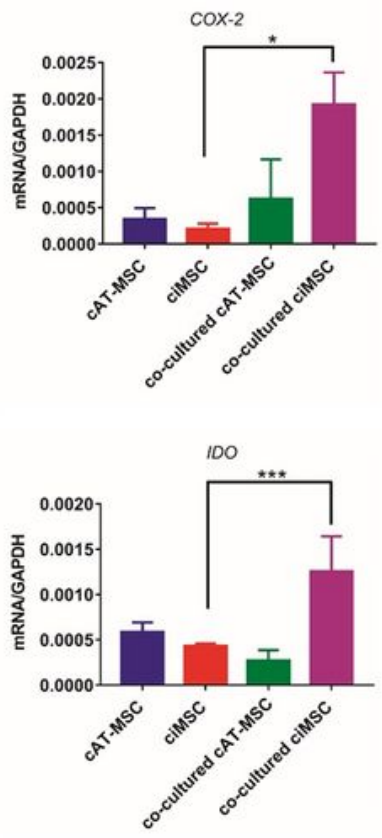

Figure 4.
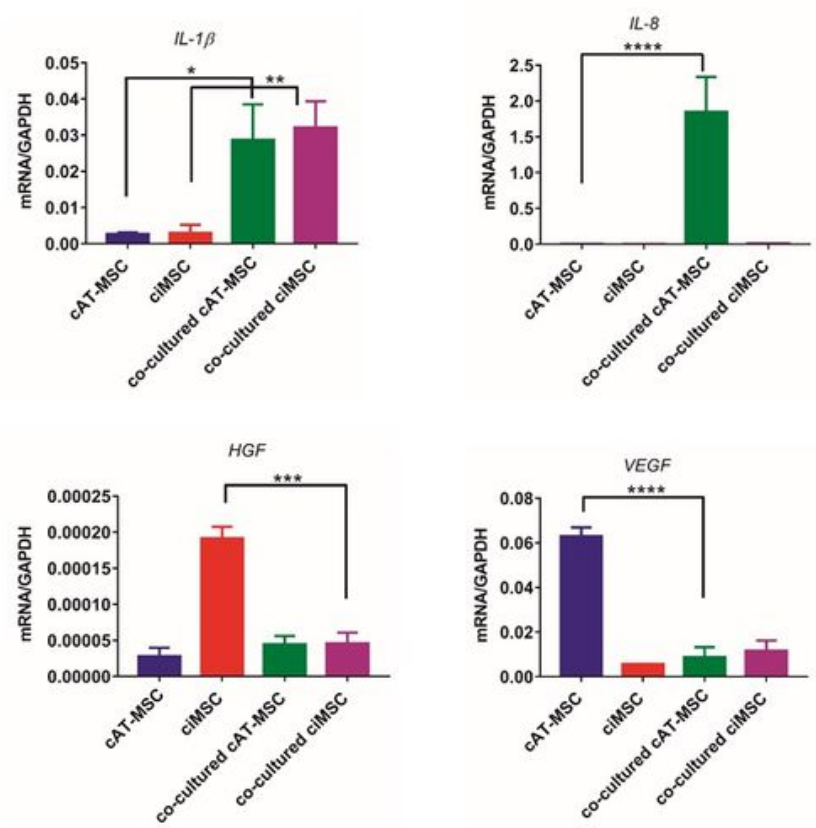

Shahsavariet al. 
Figure 4

Effect of mitogen-stimulated canine lymphocytes on inflammatory cytokine expression of ciMSCs andcAT-MSCs. When co-cultured with mitogen-stimulated lymphocytes, ciMSCs downregulated their expression of iNOS, HGF, TGF- 31 andPTGER-2a, while increasing their expression of COX-2, IDO and IL-1 $\beta$.

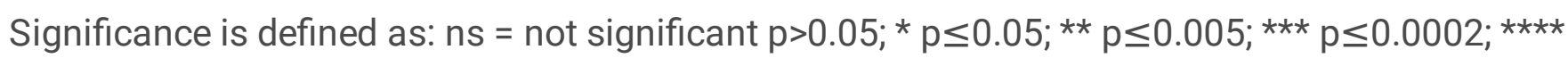
$\mathrm{p} \leq 0.0001$.

Figure 5.
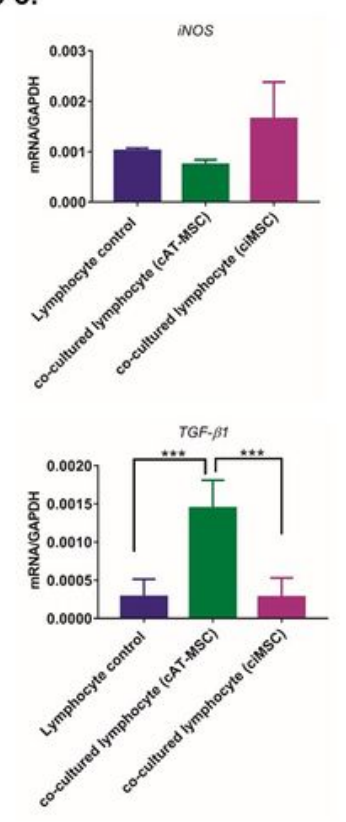
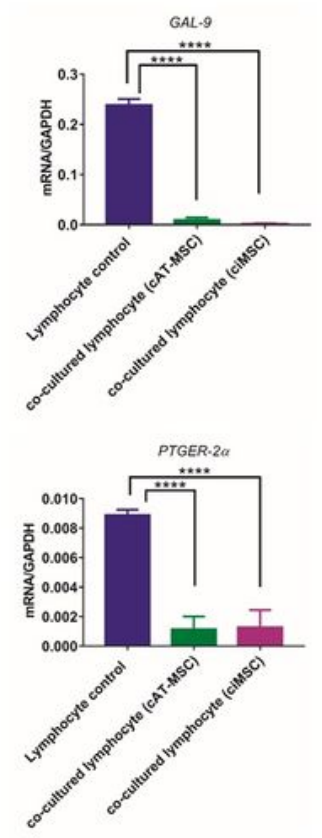

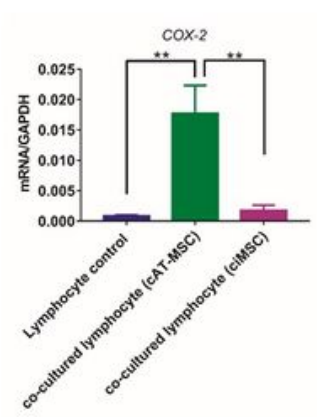

100

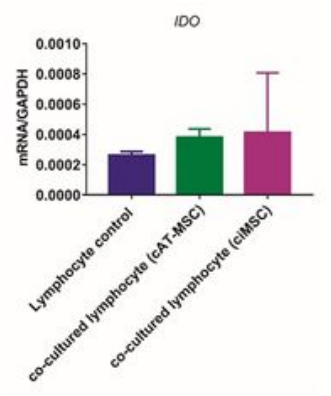

Shahsavariet al.

Figure 5 .

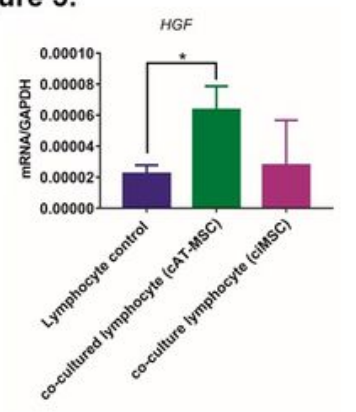

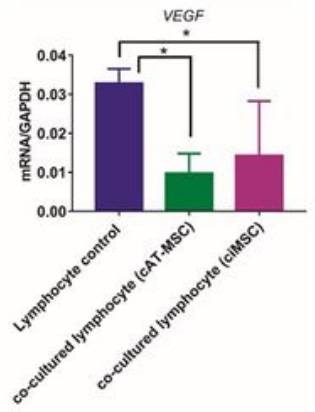

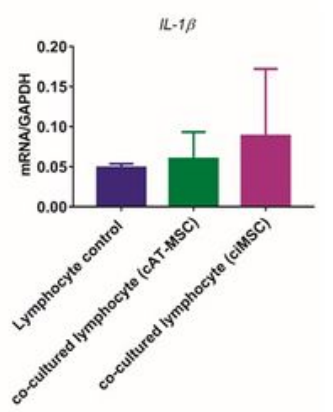

Shahsavariet al.

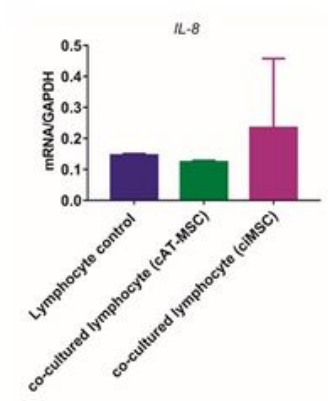




\section{Figure 5}

Effect of ciMSCs and cAT-MSCs on inflammatory cytokine expression of mitogen-stimulated canine lymphocytes.Lymphocytes cultured with ciMSCs and cAT-MSCs downregulated their expression of GAL-9, PTGER-2 $\alpha$ and VEGF, while the expression of iNOS, IDO, IL-8 and IL-1 $\beta$ were unchanged. Lymphocytes cocultured with cAT-MSCs increased their expression of COX-2andTGF- $\beta 1$. Significance is defined as: ns = not significant; $p>0.05 ; * p \leq 0.05 ; * \star p \leq 0.005 ; * \star \star ~ p \leq 0.0002 ; * \star \star * ~ p \leq 0.0001$.

Figure 6.

Shahsavari et al.
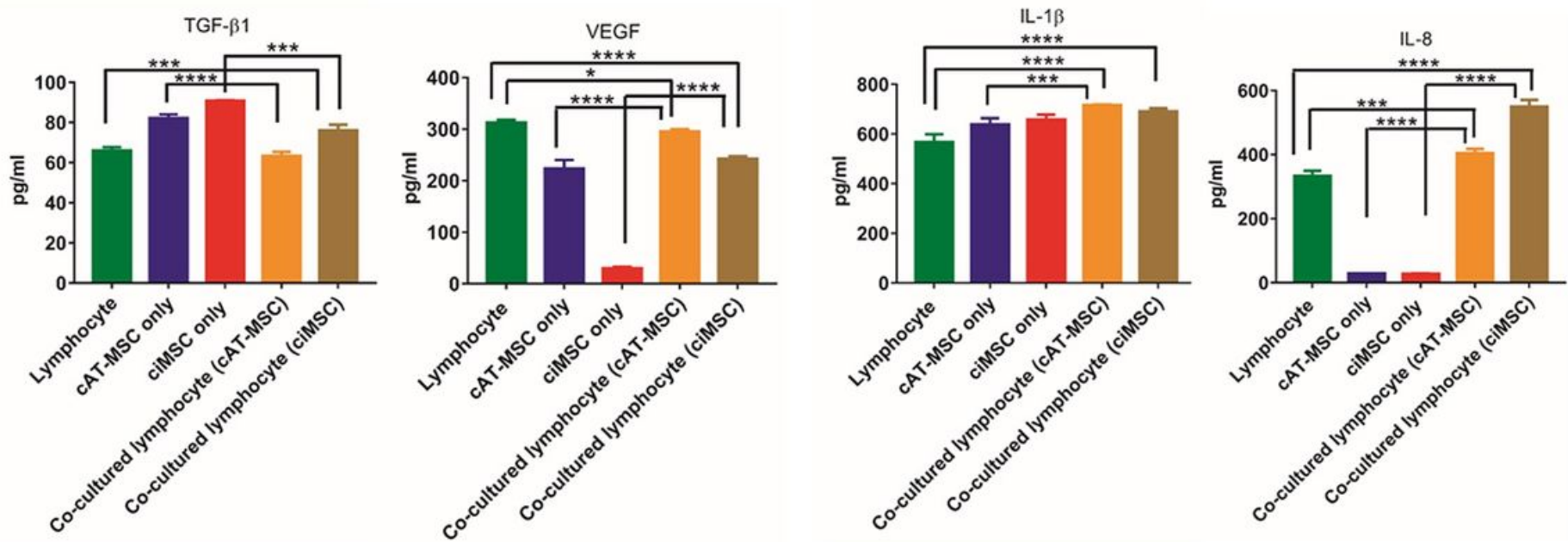

Figure 6

Effects of co-culture on the secretion of factors by lymphocytes, ciMSCs and cAT-MSCs. Lymphocytes, ciMSCs and CAT-MSCs produce IL-1 $\beta$, IL-8, TGF- $\beta 1$ and VEGF. Based on mRNA levels (see Figures 5 and 6), the increase in IL-1 $\beta$ measured in the medium from co-cultures of cMSCs and lymphocytes is likely produced by the ciMSCs and cAT-MSCs rather than the lymphocytes. When similarly referenced to mRNA levels, cAT-MSCs and lymphocytes in co-culture upregulate their expression of IL-8 while ciMSCs do not. Significance is defined as: ${ }^{\star} p \leq 0.05 ; * \star p \leq 0.005 ; * \star \star p \leq 0.0002 ; * \star \star * p \leq 0.0001$.

\section{Supplementary Files}

This is a list of supplementary files associated with this preprint. Click to download.

- ShahsavarietalSuppData1A1B.xlsx

- ShahsavarietalSupplementaryTable5.docx 
- ShahsavarietalSupplementaryTable4.docx

- ShahsavarietalSupplementaryTable3.docx

- ShahsavarietalSupplementaryTable2.docx

- ShahsavarietalSupplementaryTable1.docx 